\title{
Serum Tumor Marker Levels in Rheumatoid Arthritis
}

\section{Romatoid Artritli Hastalarda Serum Tümör Belirteçleri Düzeyleri}

\author{
Selcuk Şeber ${ }^{1}$, Dilek Solmaz ${ }^{2}$, Tarkan Yetişyiğitit ${ }^{1}$ \\ ${ }^{1}$ Namik Kemal University Hospital, Medical Oncology Clinic, Tekirdag, Turkey \\ ${ }^{2}$ Namik Kemal University Hospital, Rheumatology Clinic, Tekirdag, Turkey
}

DergiyeUlaşma Tarihi: 11/08/2016 Dergiye Kabul Tarihi: 29/11/2016 Doi: 10.5505/aot.2016.26234

\begin{abstract}
ÖZET
Giriş ve Amaç: Romatoid Artrit (RA) eklemleri etkileyen ve görece sık rastlanılan inflamatuar bir hastalıktır. $\mathrm{Bu}$ çalışmada RA tanılı hastalarda serum tümör belirteçleri olan karsinoembriyonik antijeni (CEA) ,CA 125, CA 19.9 ve CA15.3 düzeylerinin belirlenmesi amaçlanmış̧ır

Yöntem: Bir üniversite hastanesinin romatoloji kliniğinde RA tanısı ile takip edilmekte olan toplam 148 hasta çalışma grubuna ve osteoartrit tanıl 36 hasta ise kontrol grubuna dâhil edilmiştir. Çalışmaya katılan bireylerden alınan kan örneklerinden romatoid faktör (RF), eritrosit sedimantasyon hızı (ESR), anti siklik sitrilünepeptid (anti CCP) ve serum tümör belirteçleri olan CEA,CA19.9,CA 125 ve CA 15.3 düzeyleri ölçülmüştür. Hastalık aktivite skoru çalışmaya dâhil edilme sırasında ilgili romatoloji uzmanı tarafindan değerlendirilmiştir.

Bulgular: Serum CEA,CA19.9,CA 125 ve CA15.3 düzeyleri RA tanılı hastalarda kontrollere göre anlamlı olarak daha yüksek saptanmıştır. Hem aktif hem de inaktif hasta grubunda tümör belirteç düzeyleri kontrol grubuna göre anlamlı olarak yüksek ölçülmüştür ancak tümör belirteçleri ile hastalık aktivite skoru arasında bir korelasyon saptanamamıştır. Tümör belirteçleri arasında yalnızca CEA ile RF arasında bir korelasyon saptanmıştır(r 0.165, p >0.049).

Tartışma ve Sonuç: Serum tümör belirteçleri RA tanılı hastalarda sıklıkla yüksek seviyelerde saptanabilir. Hastaların takibinden sorumlu olan hekimlerin bu durumdan haberdar olmaları, bu hasta grubunda malignite varlığı araștırma amacı ile yapılabilecek olan gereksiz işlemlerin önüne geçilmesine yardımcı olacaktır.
\end{abstract}

Anahtar kelimeler: Tümör belirteçleri, Romatoid Artrit, İnflamasyon

ABSTRACT
Introduction: Rheumatoid arthritis (RA) is a relatively common inflammatory disease generally affecting the joints. This study aimed to assess the levels of various serum tumors markers; carcinoembryonic antigen (CEA), CA 125, CA 19.9 and CA15.3 in patients with a known diagnosis of RA.

Methods: A total of 148 patients who were being followed in the rheumatology clinic of a tertiary academic center with a diagnosis of RA and 36 controls were included in the study group. Measurement of rheumatoid factor (RF), erythrocyte sedimentation rate (ESR), anti CCP and serum tumor markers including CEA, CA 19.9, CA 125 , CA 15.3 were made from the blood samples obtained from the participants. Disease activity score at the time of study entry was also evaluated by the attending rheumatologist.

Results: Serum levels of CEA, CA19.9, CA 125 and CA 15.3 were found to be significantly higher in RA patients compared to controls. This difference was statistically significant in both patient groups with active and inactive disease compared to the control group. However a correlation between tumor markers and disease activity score was not found. Among tumor markers only serum CEA levels were found to be associated with RF levels (r 0.165, p >0.049)

Discussion and Conclusion: Serum tumor markers are frequently elevated in patients with RA and caring physicians should be aware of this phenomenon to avoid the use of unnecessary evaluative procedures for searching presence of malignancy in these group of patients.

Key words: Tumor markers, Rheumatoid Arthritis, Inflammation 


\section{Introduction}

Rheumatoid arthritis (RA) is the most common form of inflammatory arthritis affecting nearly $\% 1$ of the population. Chronic inflammation affecting synovial tissue is a major causes of disability in the adult population. Although the exact etiology behind RA is still obscure, RA associated antibody formation against RA related antigens is thought to be the primary initiating factor for development of overt clinical RA. In genetically susceptible individuals, autoantibody formation is followed by chronic immune system activation(1).

Through this chronic overstimulation of immune system production of several proinflammatory cytokines such as tumor necrosis factor alpha and interleukin one alpha are increased. These cytokines in return induce upregulation of cellular adhesion molecules such as intercellular adhesion molecule (ICAM) within synovial stroma and result in structural changes in the joints(2).

Presence of circulating antibodies such as rheumatoid factor (RF) and anti-cyclic citrullinated antibody (anti CCP) are commonly present in high titer in the serum of RA patients and their presence along with elevated levels of inflammatory markers such as erythrocyte sedimentation rate (ESR) and C reactive protein (CRP) play a role in the diagnosis and evaluation of disease activity(3). On the other hand tumor markers are monoclonal antibodies directed to soluble glycoproteins that are produced by tumor cells in various types of cancer. Their serum levels are used as an adjunct for evaluation of diagnosis and treatment response in several malignant diseases (4).

CA 125 and CA 15.3 are transmembrane mucin glycoproteins and their cell surface expression is found in epitheal cells, digestive and respiratory tracts. CA 125 is encoded by the MUC16 musin gene and was initially thought to be overexpressed exclusively in ovarian cancer cells. However recent studies have identified that high CA125 serum levels can be found in several other types of cancer(5). CA 15.3 is the antigen product of the MUC1 gene and is generally used as a tumor marker for breast cancer. However, CA 15-3/MUC 1 overexpression is found in several other cancer types as well(6).
CA 19.9 is another mucin glycoprotein with a carbohydrate like structure which is called as sialy Lewis A (a member of the Lewis type blood group antigens). CA 19.9 antigen is commonly overexpressed in pancreatic cancer cells however it is not specific to pancreas cancer. Like other antigens high serum levels can be found in various other cancer types and inflammatory conditions such as hepatitis(7). Carcinoembryonic antigen (CEA) is an oncofetal antigen which is normally expressed in fetal digestive tract. It plays an important role cell adhesion process. However, its abnormal expression is found in cancers of the colon, stomach, breast and lung as well as its serum level is elevated in inflammatory conditions such as cigarette smoking(8).

In this study we aimed to evaluate serum CA 15.3, CA 19.9, CA 125 and CEA levels in patients diagnosed with RA and their association with disease activity and acute phase reactants.

\section{Methods}

148 consecutive RA patients who were being followed in a tertiary academic centers' rheumatology clinic were included in the study group. RA diagnosis was made according to 1987 American College of Rheumatology Criteria(9). All of the patients were receiving active treatment for RA. Control group consisted of volunteers who were recruited from patients followed in the same clinic with diagnosis of osteoarthritis or other noninflammatory joint disorders. Patients who have a history of malignancy were excluded from the study group. Written informal consent was taken from all of the study participants and the procedures were performed in accordance with the guidelines of the Helsinki Declaration. In all of the patients, acute phase reactants (ESR and CRP) and serum tumor markers (CA15-3, CA19-9, CA 125, CEA) were evaluated from the blood samples taken from the participants. Rheumatoid factor (RF) and anti-Anti- Cyclic Citrullinated Peptide levels were also recorded if available.

Serum levels of CA15-3, CA 19-9, CA 125 and CEA were evaluated with electrochemiluminescence method (Hitachi E170 automated analyzer, Roche, Basel, Switzerland). ESR was determined by 
Westergen method while CRP was measured with nephelometry (Behring 100, Behring, Germany). Anti CCP IgG autoantibodies were detected with ELISA method (Euroimmun, Germany). Disease activity score was measured with Disease Activity Score 28 erythrocyte sedimentation rate (DAS28-ESR) criteria.

Statistical Analysis: All data were analyzed with SPSS Statistics 16.0 for Windows. Normality distribution of variables were assessed by Kolmogorov-Smirnov test. Variables with a continuous distribution were analyzed with the " $\mathrm{t}$ " test while analysis for nominal variables were done by using MannWhitney $U$ test. Distributions of continuous variables were shown as mean and standard deviation. Categorical variables were recorded as percentages $\mathrm{Ki}$ square test was used for their analysis. Correlations between variables were evaluated with Spearman test. Results were considered statistically significant, when the obtained P-value was $<0.05$. Institutional Ethical Committee approval was obtained for this study.

\section{Results:}

148 RA patients and 36 controls were included in the study group. Distribution of the demographic variables between the two groups was statistically similar (Table 1). RF was found positive in \%56.7 and anti CCP antibody levels were found positive in $\% 60.6$ of the patient group. The median duration of symptoms in RA patients were $6.8 \pm 6.9$ years. Tumor marker levels and levels of acute phase reactants were significantly higher in the patient group compared to controls (Table 2). $\% 50$ of the patient group was categorized as having active disease according to DAS 28 ESR criteria. Levels of serum tumor markers was not statistically different between RA patients with active (DAS $28 \mathrm{ESR} \leq 2.6$ ) and inactive (DAS 28>2.6) disease (Table 3). Among serum tumor markers CA 15-3, CA 19-9 and CEA had a positive correlation with increasing age while CEA levels were found to be correlated with smoking and serum RF levels. However, no significant correlation was found between tumor marker levels and CRP level and DAS 28 - ESR activity scores.

Table 1: Demographical variables of RA and control group

\begin{tabular}{|l|l|l|l|}
\hline & RA (n: 148) & Control (n:36) & p \\
\hline Age, means & $52 \pm 11.7$ & $50 \pm 11.5$ & $>0.05$ \\
\hline Gender, F/M & $128 / 29$ & $30 / 6$ & $>0.05$ \\
\hline Years of education, means & $7 \pm 3.8$ & $6 \pm 4.2$ & $>0.05$ \\
\hline Smoking history, ; $\%$ & $58 ; 37.4$ & $14 ; 38.8$ & $>0.05$ \\
\hline
\end{tabular}

Abb: RA rheumatoid arthritis, $\mathrm{F}$ female, $\mathrm{M}$ male

Table 2: Serum Acute phase reactant and tumor marker levels in RA control groups

\begin{tabular}{|l|l|l|l|}
\hline & RA $(\mathrm{n}: 148)$ & Control $(\mathrm{n}: 36)$ & $\mathrm{p}$ \\
\hline ESR, means & $23 \pm 18.6$ & $16 \pm 11.0$ & 0.036 \\
\hline $\mathrm{CRP}$, mean \pm SD & $8.2 \pm 10.8$ & $3.9 \pm 4.1$ & 0.005 \\
\hline CA 125, mean \pm SD & $23.1 \pm 47.3$ & $12.5 \pm 4.6$ & 0.029 \\
\hline CA 15-3, mean \pm SD & $20.8 \pm 11.4$ & $15.4 \pm .9$ & 0.005 \\
\hline CA 19-9, mean \pm SD & $15.8 \pm 23.4$ & $10.7 \pm 8.0$ & 0.043 \\
\hline CEA, mean \pm SD & $4.0 \pm 17.8$ & $1.7 \pm 1.8$ & 0.002 \\
\hline
\end{tabular}

Abb: SD standard deviation, RA rheumatoid arthritis, CRP C reactive protein

Table 3: Tumor marker levels in patients with active and inactive disease

\begin{tabular}{|l|l|l|l|}
\hline & İnactive disease (n:76) & Active disease (n: 72) & $\mathrm{p}$ \\
\hline $\mathrm{CA} 125$, mean \pm SD & $17.8 \pm 15.6$ & $29.3 \pm 67.8$ & $>0.05$ \\
\hline CA 15-3, mean \pm SD & $20.9 \pm 12.9$ & $20.9 \pm 9.6$ & $>0.05$ \\
\hline CA 19-9, mean \pm SD & $10.8 \pm 30.6$ & $10.9 \pm 11.1$ & $>0.05$ \\
\hline CEA, mean \pm SD & $2.1 \pm 1.5$ & $5.6 \pm 24.4$ & $>0.05$ \\
\hline
\end{tabular}

Abb: SD standard deviation 
Table 4: The correlations between serum tumor marker levels with disease activity, RF, CRP, age and smoking history

\begin{tabular}{|l|l|l|l|l|l|l|}
\hline & & age & $\begin{array}{l}\text { Smoking } \\
\text { history }\end{array}$ & CRP & RF & $\begin{array}{l}\text { DAS28 } \\
\text { ESR }\end{array}$ \\
\hline CA 125 & $\mathrm{r}$ & -.014 & 0.057 & -.050 & 0.085 & 0.093 \\
\hline & $\mathrm{p}$ & 0.869 & 0.498 & 0.548 & 0.318 & 0.273 \\
\hline CA 15-3 & $\mathrm{r}$ & 0.203 & -.076 & -.082 & 0.013 & 0.080 \\
\hline & $\mathrm{p}$ & 0.016 & 0.363 & 0.322 & 0.873 & 0.337 \\
\hline CA 19-9 & $\mathrm{r}$ & 0.346 & -.075 & 0.066 & 0.033 & 0.134 \\
\hline & $\mathrm{p}$ & $<0.001$ & 0.367 & 0.424 & 0.696 & 0.109 \\
\hline CEA & $\mathrm{r}$ & 0.299 & 0.247 & -.019 & 0.165 & -.052 \\
\hline & $\mathrm{p}$ & $<0.001$ & 0.003 & 0.815 & 0.049 & 0.533 \\
\hline
\end{tabular}

Abb: CRP C reactive protein, RF rheumatoid factor, DAS28 ESR Disease Activity Score 28

Erytocyte Sedimentation Rate

\section{Conclusion}

Theoretically production of various serum tumor markers is closely associated with inflammation besides the presence of cancer producing cells. In this study we aimed to investigate whether serum tumor markers are elevated in presence of RA which is itself an inflammatory condition and also evaluate whether their levels are associated with disease activity and other commonly used markers of systemic inflammation.

Carcinoembryonic antigen (CEA), an oncofetal protein normally expressed in mucosal tissues, is over expressed in tumoral tissue and therefore regarded as a marker of malignancy. High levels have been documented to be present in a wide array of different cancer types such as colonic, gastric, breast and lung cancers. However high CEA levels has also been associated with the presence of inflammatory conditions. Studies have shown that cigarette smoking can induce increased production of CEA expression at the cellular level in normal (non-cancerous) lung parenchyma. It was also suggested that in smokers high CEA levels were closely associated with high neutrophil levels which is a sign of presence of inflammation(10).

Therefore, we can hypothesize that increased CEA levels in patients with RA is a reflection of proinflammatuary state. In our findings, CEA levels have been found to be correlated with smoking history and serum RF levels however a correlation between disease activity score and CEA was not present. This finding is in accordance with another study also evaluating the level of serum tumor markers in RA patients in which disease activity was measured by DAS28 however in two other studies which also reported elevated CEA levels in RA patients, a correlation between $\mathrm{RF}$ and CEA levels were not found(11-13).

Of interest there are a few studies in the literature that suggest CEA itself by binding to monocytes can trigger increased secretion of proinflammatuary cytokines such as tumor necrosis factor alfa, interleukin 1 beta and interleukin 6. These cytokines have a pivotal role in the pathogenesis of RA $(14,15)$.

Similarly, CA 125, a glycoprotein normally expressed in coelomic epithelium during fetal development, is overexpressed in ovarian cancer as well as many other benign or malign conditions which are associated with fluid collection in peritoneum such as peritoneal metastatic disease, cirrhosis or congestive heart failure or endometriosis. CA-125 is a glycoprotein which is also known as MUC16. It is expressed on the cell surface and is responsible for cell adhesion to neighboring tissues(16).

Although CA-125 expression is not present in the affected tissues by rheumatoid arthritis; it has been postulated that CA 125 secretion from the mesothelium can increase by stimulation of mesothelial cells by cytokines such as IL 1 alpha and TNF alpha(17).CA 125 levels in RA patients in comparison to normal controls has been previously evaluated by Berfamashi et al. and Szekanecz et al. While Berfamaschi et al. reported CA 125 
levels were not significantly elevated in RA patients compared to controls, Szekanecz et al. found that CA125 levels were significantly elevated in the patient group. In our study group CA 125 levels were found to be significantly higher in RA patients $(11,12)$.

Carbohydrate antigen 19-9 (CA 19-9) is a tumor associated oligosaccharide oncofetal antigen which is closely related to the sialylated Lewis blood group antigen (sLea). High serum levels are commonly associated with pancreatic cancer or cholangiocarcinoma as well as many other cancer types (7). sLea plays a pivotal role in adhesion of leukocytes to the inflamed joint by acting as a ligand for various cell adhesion molecules. This process is a key event in the pathogenesis of RA. Studies have suggested that sLea and cell adhesion molecule expressions may be upregulated by the same pathway in the presence of pro inflammatory cytokines in patients with inflammatory arthritis (18).

Cancer antigen 15-3 (CA 15-3) is produced by the MUC-1 gene.MUC1 gene expression is widely expressed throughout the epithelial lining and responsible for maintaining integrity of the epithelial track.MUC1 gene is not normally expressed in the connective tissue however it has been shown that MUC1 gene expression is upregulated in response to proinflammatory cytokines such as s IL- $1 \beta$, IL-6, TNF- $\alpha$, and IFN- $\gamma$ which are all found to be increased in patients with RA $(19,20)$.

The common denominator between CEA, CA 19-9, CA125 and CA 15-3 is that they are all glycoprotein antigens and have pivotal roles in intercellular adhesion and in cellular migration. It is hypothesized that overexpression of these adhesive antigens in cancer may play roles in increased tumorigenicity and undifferentiation of cancer cells. It is also possible that in the presence of inflammatory conditions such as RA, a common upregulatory process could result in overexpression of these adhesive antigens and increase synovial intercellular adhesion in the affected joints (21-23).

The relatively small sample size of patients with active disease in the study group may have prevented us from observing the correlation between the disease activity score and tumor marker serum levels. Although cancerous disease was not diagnosed in any of the subjects during the study period; it is possible that with a sufficiently longer follow up duration developing malignancies in some of the subjects with high tumor markers could have been detected. These limitations should be taken into account when interpreting the results of this study.

In conclusion, the levels of serum tumor markers, CEA, CA 19-9, CA125 and CA 15-3 are frequently increased in patients with RA. Their levels can be elevated even in well controlled disease. Only CEA levels were found to be positively correlated with RF levels. Elevated tumor markers in RA patients can solely be a marker of inflammation and not necessarily indicate presence of cancer.

\section{Conflict of Interest: None}

\section{REFERENCES}

1. Gerlag DM, Norris JM, Tak PP. RA: from risk factors and pathogenesis to prevention: Towards prevention of autoantibody-positive rheumatoid arthritis: from lifestyle modification to preventive treatment. Rheumatology (Oxford) [Internet]. 2015;kev347.

2. Siebert S, Tsoukas A, Robertson J, Mcinnes I. Cytokines as Therapeutic Targets in Rheumatoid Arthritis and Other Inflammatory Diseases. Pharmacol Rev. 2015;67(April):280-309

3. Shen R, Ren X, Jing R, Shen X, Chen J, Ju S YC. Rheumatoid Factor, Anti-Cyclic Citrullinated Peptide Antibody, C-Reactive Protein, and Erythrocyte Sedimentation Rate for the Clinical Diagnosis of Rheumatoid Arthritis. Lab Med. 2015;46(3):226-9

4. Perkins GL, Slater ED, Sanders GK, Prichard JG. Serum tumor markers. Am Fam Physician. 2003;68(6):1075-82

5. Streppel MM, Vincent A, Mukherjee R, Campbell NR, Chen SH, Konstantopoulos K, et al. Mucin 16 (cancer antigen 125) expression in human tissues and cell lines and correlation with clinical outcome in adenocarcinomas of the pancreas, esophagus, stomach, and colon. Hum Pathol. 2012;43(10):175563

6. Kufe DW. MUC1-C Oncoprotein as a Target in Breast Cancer; Activation of Signaling Pathways and Therapeutic Approaches. Oncogene. 2013;32(9):1073-81

7. Yue T, Maupin KA, Fallon B, Li L, Partyka K, Anderson MA, et al. Enhanced discrimination of malignant from benign pancreatic disease by measuring the CA 19-9 antigen on specific protein carriers. PLoS One. 2011;6(12)

8. Ballesta AM, Molina R, Filella X, Jo J GN. Carcinoembryonic antigen in staging and follow-up of patients with solid tumors. Tumour Biol. 1995;16(1):36-41

9. Arnett FC, Edworthy SM, Bloch D a, McShane DJ, Fries JF, Cooper NS, et al. The American Rheumatism Association 1987 revised criteria for the 
classification of rheumatoid arthritis. Arthritis Rheum. 1988;31(3):315-24

10. Kashiwabara K, Nakamura H, Kiguchi T, Yagyu H, Kishi K MK. Carcinoembryonic antigen and neutrophils in healthy smokers. Nihon Kyobu Shikkan Gakkai Zasshi. 1997;35(2):154-9

11. Strange A, Capon F, Spencer CC, Knight J, Weale $\mathrm{ME}$, Allen $\mathrm{MH}$, et al. A genome-wide association study identifies new psoriasis susceptibility loci and an interaction between HLA-C and ERAP1. Nat Genet [Internet]. 2010/10/19 ed. 2010;42(11):985-90

12. Szekanecz E, Sandor Z, Antal-Szalmas P, Soos L, Lakos G, Besenyei T, et al. Increased production of the soluble tumor-associated antigens CA19-9, CA125, and CA15-3 in rheumatoid arthritis: Potential adhesion molecules in synovial inflammation? In: Annals of the New York Academy of Sciences. 2007. p. 359-71

13. Unger A, Panayi GS LM. Carcinoembryonic antigen in rheumatoid arthritis. Lancet. 1974;1:791-3

14. Ganguly A, Yeltsin E, Robbins J. Identification of a carcinoembryonic antigen binding protein on monocytes. In: Biochemical and Biophysical Research Communications. 2003. p. 319-23

15. Aarons CB, Bajenova O, Andrews C, Heydrick S, Bushell KN, Reed KL, et al. Carcinoembryonic antigen-stimulated THP-1 macrophages activate endothelial cells and increase cell-cell adhesion of colorectal cancer cells. Clin Exp Metastasis. 2007;24(3):201-9

16. Rump A, Morikawa Y, Tanaka M, Minami S, Umesaki N, Takeuchi M MA. Binding of ovarian cancer antigen CA125/MUC16 to mesothelin mediates cell adhesion. J Biol Chem. 2004;279(10):9190-8
17. Zeillemaker a $M$, Verbrugh $H$ a, Hoynck van Papendrecht a a, Leguit P. CA 125 secretion by peritoneal mesothelial cells. J Clin Pathol. 1994;47(3):263-5

18. Fabris C, Falleti E, Pirisi M, Soardo G, Toniutto P, Vitulli D, Bortolotti N, Gonano F BE. Non-specific increase of serum carbohydrate antigen 19-9 in patients with liver disease associated with increased circulating levels of adhesion molecules. Clin Chim Acta. 1995;243(1):25-33

19. Li X, Wang L, Nunes DP, Troxler RF, Offner GD. Pro-inflammatory cytokines up-regulate MUC1 gene expression in oral epithelial cells. J Dent Res [Internet]. 2003;82(11):883-7

20. Celeste S, Santaniello A, Caronni M, Franchi J, Severino A, Scorza R, et al. Carbohydrate antigen 15.3 as a serum biomarker of interstitial lung disease in systemic sclerosis patients. Eur J Intern Med. 2013;24(7):671-6

21. Dettke M, Pálfi G, Pursch E, Fischer MB, Loibner H. Increased expression of the blood group-related Lewis $\mathrm{Y}$ antigen on synovial fluid granulocytes of patients with arthritic joint diseases. Rheumatology (Oxford) [Internet]. 2001;40(9):1033-7

22. Koch AE, Burrows JC, Haines GK, Carlos TM, Harlan JM LS. Immunolocalization of endothelial and leukocyte adhesion molecules in human rheumatoid and osteoarthritic synovial tissues. Lab Invest. 1991;64(3):313-20

23. Ilantzis C, Demarte L, Screaton RA, Stanners CP. Deregulated Expression of the Human Tumor Marker CEA and CEA Family Member CEACAM6 Disrupts Tissue Architecture and Blocks Colonocyte Differentiatio. Neoplasia. 2002;4(2):151-63 